\title{
「脳トレ」を検証する
}

\section{No gain from brain training}

Alla Katsnelson 2010 年 4 月 22 日号 Vol. 464 (1111)

www.nature.com/news/2010/100420/full/4641111a.html

パソコンを使った「脳トレ」で知的能力は向上しないという研究成果が発表された。

「脳トレ」ゲームの効果に関して、これ までで最大規模の検証が行われた。今 回、英国の研究者と英国放送協会 $(\mathrm{BBC})$ の Lab UK というウェブサイトは共同 で、BBCの科学番組「Bang Goes the Theory」の視聴者に、 1 日最低 10 分間、 週 3 回、オンラインで「脳トレ」課題 に取り組んでもらった。被験者は 18 60 歳までの合計 1 万 1430 人に上り、 実験は 6 週間にわたって行われた。

被験者のうち、第一グループは、一般 知能に相関する論理的思考力、計画能力、 問題解決能力に関する課題を行い、第二 グループは、市販の「脳トレ」ソフトの 対象になっている短期記憶、注意力、視 空間能力、計算力といった知的機能の訓 練を行った。そして第三グループは、対 照群として、難解な質問の答えをイン ターネットで見つけるだけの作業を行つ た。その結果、それぞれの課題に関して は成績が上がったが、研究者チームは、 どのグループも、記憶、論理的思考、学 習といった一般認知能力を測定する試験 の成績は上がらなかったとしている。

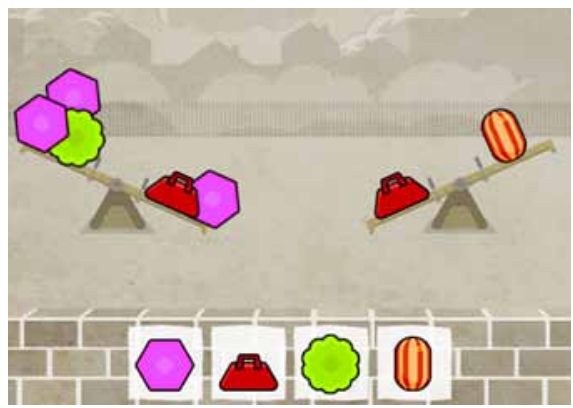

いちばん重いものはどれか。実験の課題の 1 つ。
「訓練を行った個別課題から一般的な 認知機能検査への転移効果は、全くみら れませんでした。広範な認知課題の訓練 で頭がよくなるという期待には、全く根 拠がないと思います」。こう話すのは、 今回の研究のリーダーで、医学研究会議 (MRC) 認知脳科学部門（英国ケンブ リッジ）に所属する神経科学者 Adrian Owen だ。

この研究結果は、2010 年 4 月 20 日の Nature 電子版で発表された ${ }^{1}$ が、これで 脳トレ論争が沈静化することはないだろ う。ブラウン大学アルパート・メディカ ル・スクール（米国ロードアイランド州 プロビデンス）で老化を研究する神経学 者Peter Snyderは、今回の研究はちょつ と気がかりです。実験に問題があると思 うのです」と話す。ただし Snyder も、 脳トレの有効性を裏付けるデータがそし いことを認めている。脳トレソフトを販 売している Posit Science 社 (米国カリ フォルニア州サンフランシスコ）が資金 を提供した研究 ${ }^{2}$ など、一部の先行研究 では適度の効果が実証されたが、Snyder が最近発表したメ夕解析ではほとんど効 果が認められなかったのだ 3 。

しかし、大部分の市販ソフトが、記憶 と思考能力の衰退を恐れる 60 歳以上の 成人向けに作られている、と Snyder は いう。「比較をするのなら、同一条件で 行う必要があります」。さらに、被験者 グループの年齢が上がると、初期スコア の平均值が低くなり、成績のばらつきも 大きくなるので、訓練によって有意義な 効果が得られる余地は増える、と続ける。
「健常者での超人的な効果を求めなけれ ば、脳トレの効果は現れてくるのではな いでしょうか」。

確かに、今回の被験者は、自ら進んで 集まった人々であり、「この種のゲーム で遊びたいともともと思っていたと考 えられます」と、MRC 聴覚研究所（英 国ノッティンガム）所長で、パソコン 用の脳トレソフト「マインドフィット (MindFit)」を販売する MindWeavers 社（英国オックスフォード）の創業者、 David Moore は話す。

Moore と Snyder は、トレーニング 時間が短すぎた可能性も指摘する。1 回 当たり 10 分のトレーニングが平均 24 回では、合計 4 時間のトレーニングに しかならない。「6週間で 4 時間のトレー ニングは、有意義な効果を生み出す十分 な時間とはいえません」と Snyder はい う。Moore も、「例えば弱視の治療や脳 卒中後の訓練法の 1 つとしての脳トレ は、より多くの時間が必要です」と話す。

これに対して Owen は、似たような いくつかの研究で 6 週間の訓練期間が 設定されていたと反論する。Owenによ れば、確かにトレーニングの平均回数は 24 回だったが、なかには最低 2 回から 最高は「筋金入りの脳トレファンの数百 回」という者が抢り、これら両極端の被 験者の間に成績の違いはみられなかった という。「6 週間のトレーニングで全く 効果がなく、22 週目になって突然効果 が現れるかもしれませんが、これは理論 的な現象ではありません」。

Owen 自身、今回の知見は、幼児や高 齢の患者にトレーニングを行うことが必 ずしも無䭾なことを意味している訳では ないとしている。しかし「いまだ強力な 証拠はなく、誰かが思い切って検証を行 う必要があります」と語っている。

(翻訳 : 菊川要)

1. Owen, A. M. et al. Nature advance online publication doi:10.1038/nature09042 (20 April 2010).

2. Smith, G. E. et al. J. Am. Geriatr. Soc. 57, 594-603 (2009)

3. Papp, K. V., Walsh, S. J. \& Snyder, P. J. Alzheimers Dement. 5 , 50-60 (2009)

参考動画

http://www.youtube.com/watch?v=SDU1PraJYt8 